\title{
Growth associated proteins in tumor cells and stroma related to disease progression of colon cancer accounting for tumor tissue $\mathrm{PGE}_{2}$ content
}

\author{
CHRISTIAN CAHLIN, CHRISTINA LÖNNROTH, ANNETTE ARVIDSSON, \\ SVANTE NORDGREN and KENT LUNDHOLM
}

Department of Surgery, Surgical Metabolic Research Laboratory at Lundberg Laboratory

for Cancer Research, Sahlgrenska University Hospital, Göteborg, Sweden

Received November 1, 2007; Accepted December 28, 2007

\begin{abstract}
Connections among specific proteins (Bax, Bcl-2, bFGF, COX-1, COX-2, E-cad, p15, p53, PCNA, TGFß3, TUNEL, vWF) in control of cell proliferation, apoptosis, cell adhesion, tumor vascularity and $\mathrm{PGE}_{2}$ content were evaluated in colon cancer as related to disease progression and survival. Tumor tissue and adjacent normal colon mucosa were obtained at curative resection in 22 patients. $\mathrm{PGE}_{2}$ concentrations were assessed in tumor tissue and tumor derived blood, splanchnic blood, peripheral venous blood and urine. Host inflammation was determined (CRP, ESR) in relationship to tumor differentiation and stage. Patients survived as expected according to Dukes A-D staging. Growth-related proteins correlated between tumor cells and stroma as well as between protein factors within tumor cells and tumor stroma. COX-2 predicted tumor tissue content of $\mathrm{PGE}_{2}(\mathrm{p}<0.002)$, without reflection in tumor derived blood. Systemic inflammation was predicted by p15, TGFB3 and $\mathrm{Bcl}-2$ in tumor tissue $(\mathrm{p}<0.001) . \mathrm{p} 15$ and $\mathrm{vWF}$ predicted reduced survival in ungrouped patients $(\mathrm{p}<0.02)$, while $\mathrm{p} 15$, PCNA, TGFß3 and vWF predicted reduced survival $(p<0.0001)$ when patient grouping accounted for high tumor content of $\mathrm{PGE}_{2}$. Our results connect systemic inflammation and survival to COX-2 staining and increased $\mathrm{PGE}_{2}$ in colon cancer. Thus, it seems important to understand proximal signals behind upregulation of COX-2 and subsequent $\mathrm{PGE}_{2}$ production in certain tumor cells in colon cancer.
\end{abstract}

Correspondence to: Professor Kent Lundholm, Department of Surgery, Sahlgrenska University Hospital, SE 41345 Göteborg, Sweden

E-mail: kent.lundholm@surgery.gu.se

Abbreviations: CRP, C-reactive protein; ESR, erythrocyte sedimentation rate

Key words: COX-1, COX-2, survival

\section{Introduction}

Experimental tumors are comparatively homogeneous regarding cell clones, cell appearance and the metabolic characteristics of cells pending analyses in viable and vascularized tissue. By contrast, spontaneously growing human malignant tumors are much more heterogeneous in histological and metabolic appearance in part depending on the content and properties of various invading host cells (1). This fact has made it difficult to judge clinical tumors from overall functional aspects. Thus, it is likely that clinical progression is predicted by certain cell clones in a particular area within a tumor where prerequisites for growth, proliferation and desquamation of metastatic noduli are appropriately provided. This dilemma was particularly obvious to us in evaluation of characteristics of arachidonic acid metabolites in previous investigations showing that various tumors contain areas with or without visible cyclooxygenases (COX-1/COX-2), which may relate to outcome (2-7). Thus, expression or content of certain tissue/tumor growth-factors within stroma and tumor epithelial cells in human cancer may imply different functions in the presence of high or low eicosanoid content (8), which has support in recent epidemiological observations (9). Therefore, the present study was aimed at estimating steady state levels of tumor tissue protein factors important for events such as cell proliferation, apoptosis, angiogenesis and cell adhesion in colon cancer of different stage and differentiation. Secondary aims were to relate such tumor protein factors to inflammation at both tumor $\left(\mathrm{PGE}_{2}\right.$ content) and systemic levels (C-reactive protein, erythrocyte sedimentation rate) and to evaluate by mathematical modeling how different protein factors predicted outcome accounting for low and high content of $\mathrm{PGE}_{2}$ in tumor tissue.

\section{Patients and methods}

Patients and specimens. During the years 1995-1996 tumor tissue/samples from 22 patients operated on for colon adenocarcinoma at Sahlgrenska University Hospital were collected. A part of the tumor and adjacent normal bowel wall were put in $4 \%$ buffered formaldehyde solution for three days at $4^{\circ} \mathrm{C}$, 
washed and kept in 70\% ethanol until dehydration and paraffinembedding (for immunohistochemistry), or immediately put in ice-cold 0.1 M Tris-HCl buffer, $\mathrm{pH} 7.4$ (for analysis of $\mathrm{PGE}_{2}$ concentration). Remaining resected specimens were sent for routine histological examination. At operation, blood was drawn from a peripheral vein, a splanchnic vein draining the tumor and from a splanchnic vein without tumor drainage. At the same occasion urine was collected. $\mathrm{PGE}_{2}$ was analyzed in all samples. Medical files from all patients were recorded. Tumors were classified according to stage and differentiation by a certified pathologist accounting for clinical observations preoperatively (ultrasound, CT scan, MR scan) and at surgery. Tumors were grouped histologically as high, moderate and poor differentiated. Dukes' classification was provided for tumor stage. Briefly, Dukes A denotes a colorectal adenocarcinoma confined to the mucosa, in Dukes B the tumor grows through the muscle layers of the bowel, in Dukes $\mathrm{C}$ the tumor has spread to the regional lymph nodes and in Dukes D distant metastases are present (10), corresponding to stage I-IV. None of the patients received neoadjuvant therapy according to our routine procedures 1995-1996.

The patients have been followed-up until September 2006 or until death. Information about time and cause of death were collected from the Swedish registry of death causes. No patient was lost to follow-up.

$P G E_{2}$ analysis. Venous blood sampling was performed during surgery. Sodium citrate was used as an anticoagulant and indomethacin $(10 \mu \mathrm{g} / \mathrm{ml})$ was used as inhibitor to prevent breakdown of arachidonic acid in samples. Specimens were kept on ice and centrifuged at $2500 \mathrm{x} \mathrm{g}$ for $10 \mathrm{~min}$ at $4^{\circ} \mathrm{C}$. Urine was collected simultaneously and handled in the same way. Tumor samples and mucosa were immediately homogenized in $0.1 \mathrm{M}$ Tris- $\mathrm{HCl}$ buffer, $\mathrm{pH} 7.4$, containing indomethacin as specified above. Following acidification, ethanol addition and centrifugation of plasma, urine and homogenized tissue, $\mathrm{PGE}_{2}$ was extracted on Amprep C 18 mini-columns (Amershan RPN 1900), according to recommendations (Amershan RPA 530). Radioimmunoassays were performed within 6 days following conversion of extracted $\mathrm{PGE}_{2}$ by methyl oximation according to kit instructions. Mean values were calculated from duplicates.

Immunohistochemistry. Formalin-fixed and paraffin-embedded tissue sections $(4 \mu \mathrm{m})$ were deparaffinized in xylene and passed through graded ethanol according to standard procedure. Sections for PCNA detection were fixed in acetone for $5 \mathrm{~min}$ and incubated with $1 \%$ NP40 for 5 min (11). All other sections were rinsed twice in $5 \mathrm{mM}$ Tris-buffered saline (TBS), $\mathrm{pH} 7.8$ and either trypsinated for $15 \mathrm{~min}$ at $37^{\circ} \mathrm{C}$ (60 mg trypsin; $150 \mathrm{mg} \mathrm{CaCl}{ }_{2}$ in $150 \mathrm{ml}$ TBS) (Sigma) or microwave-radiated for antigen retrieval in $10 \mathrm{mM}$ citrate buffer, $\mathrm{pH} 6.0$ (5 min$350 \mathrm{~W} ; 1$ min rest; 4 min-350 W). Sections were rinsed in TBS and mounted with Shandon Cover Plates. Primary and secondary antibodies as well as all enzyme conjugates were diluted in 5\% non-fat dry milk in TBS. Rinsing with TBS between incubations was performed. Non-specific protein binding was blocked with dry milk in TBS, followed by blocking with one of the following immunoglobulins for $30 \mathrm{~min}$ at room temperature (RT): normal rabbit $\mathrm{IgG}$ (Dako
X0903), diluted $1 / 8000(2.5 \mu \mathrm{g} / \mathrm{ml})$ or normal rabbit $\mathrm{IgG}$ (sc-2027), diluted 1/500, normal goat IgG (sc-2028), diluted $1 / 500(1 \mu \mathrm{g} / \mathrm{ml})$, normal mouse IgG2b (Dako X0944) $(4 \mu \mathrm{g} /$ $\mathrm{ml}$ ), normal mouse IgG2a (Dako X0943), diluted 1/100 (1 $\mu \mathrm{g}$ / $\mathrm{ml}$ ). Endogenous biotin was blocked with avidin/biotin blocking kit (Vector). Primary antibodies are listed in Table I. For negative controls, one of the following immunoglobulins was used to match the species and the $\operatorname{IgG}$ concentration of the primary antibody: normal rabbit IgG (Dako X0903) or normal rabbit IgG (sc-2027), normal goat IgG (sc-2028), normal mouse IgG2b (Dako X0944) or normal mouse IgG2a (Dako X0943), and incubated in parallel to antibody sections. Specificity for COX-1 and COX-2 antibodies was validated by neutralization with blocking peptides sc-1752 P, sc-1746 $\mathrm{P}$ in a 10-fold excess of peptide, preincubated for $2 \mathrm{~h}$ at $\mathrm{RT}$ and then incubated in parallel to antibody and negative control sections overnight $(\mathrm{ON})$ at $4^{\circ} \mathrm{C}$. One of the following secondary antibodies was used for 30-min incubation at RT: biotinylated donkey anti-rabbit IgG (Amersham RPN1004), diluted 1/300, biotinylated rabbit anti-goat IgG (Dako E0466), diluted 1/500, biotinylated goat anti-rabbit IgG (sc-2040), diluted 1/400, biotinylated goat anti-mouse IgG (sc-2039), diluted biotinylated horse anti-mouse IgG (Santa Cruz ABC system), diluted 1/200 was incubated for $30 \mathrm{~min}$ at RT. Streptavidin-alkaline phosphatase conjugate (Amersham RPN1234), diluted 1/150 was added to all sections and incubated for $30 \mathrm{~min}$ at RT. Sections were demounted, rinsed and color-developed for $20 \mathrm{~min}$ in Fast Red Substrate System (Dako K0699) with endogenous alkaline phosphatase-inhibitor Levamisole included. Counterstaining was performed in Mayers hematoxylin. Mount-Quick Aqueous (Daido Sangyo Co., Ltd., Japan) was used for mounting.

Quantification of immunohistochemical staining. Sections from all evaluated tumors and normal bowel wall were stained at the same occasion with the same batches of reagents for each antigen to minimize variability of the procedure among specimens. Consecutive sections $(4 \mu \mathrm{m})$ were used for staining of the antigens. It was possible to identify the same areas in the sections of all antigens. Thereby, the expression of the different antigens could be estimated and compared in defined areas of the tumor and bowel wall. The expressions of COX-2 was assessed as the first procedure indicating that expression was quite variable across sections in most tumors. Therefore, areas with high and low COX-2 expression were identified in tumor sections; so called hot spots. In such sections from each tumor, 3-4 areas with expression of COX-2 were evaluated. The subsequent assessment of IHC staining for the other antigens were then estimated across these areas in order to create a relationship between COX-2 and other growth related proteins.

For each antigen the IHC staining was given a value between $0-5$. Zero indicates no staining and 5 maximal staining intensity. Thereby, the specific expression pattern for each antigen, i.e. mainly staining of the nucleus, cytoplasm, membranes, smooth or granular staining were taken into account. In tumor tissue the malignant cells and stroma were separately assessed. The staining of epithelium, submucosa, smooth muscles and blood vessels were recorded separately in the normal bowel wall. 
Table I. Antibodies used for immunohistochemistry.

\begin{tabular}{|c|c|c|c|c|c|}
\hline Primary antibody & Isotype & Supplier & Product no. & Concentration $\mu \mathrm{g} / \mathrm{ml}$ & Antigen retrieval \\
\hline $\begin{array}{l}\text { Bax rabbit affinity- } \\
\text { purified polyclonal }\end{array}$ & & $\begin{array}{l}\text { Santa Cruz } \\
\text { Biotechnology }\end{array}$ & sc-493 & 0.25 & Trypzination \\
\hline $\begin{array}{l}\text { Bcl-2 rabbit affinity- } \\
\text { purified polyclonal }\end{array}$ & & $\begin{array}{l}\text { Santa Cruz } \\
\text { Biotechnology }\end{array}$ & sc-492 & 0.25 & Trypzination \\
\hline $\begin{array}{l}\text { bFGF rabbit affinity- } \\
\text { purified polyclonal }\end{array}$ & & $\begin{array}{l}\text { Santa Cruz } \\
\text { Biotechnology }\end{array}$ & sc-79 & 1 & Trypzination \\
\hline $\begin{array}{l}\text { COX-1 goat affinity- } \\
\text { purified polyclonal }\end{array}$ & & $\begin{array}{l}\text { Santa Cruz } \\
\text { Biotechnology }\end{array}$ & sc- 1752 & 1 & Trypzination \\
\hline $\begin{array}{l}\text { COX-2 goat affinity- } \\
\text { purified polyclonal }\end{array}$ & & $\begin{array}{l}\text { Santa Cruz } \\
\text { Biotechnology }\end{array}$ & sc-1746 & 1 & Trypzination \\
\hline $\begin{array}{l}\text { E-cadherin goat affinity } \\
\text { purified polyclonal }\end{array}$ & & $\begin{array}{l}\text { Santa Cruz } \\
\text { Biotechnology }\end{array}$ & sc- 1500 & 0.25 & Trypzination \\
\hline $\begin{array}{l}\text { p15 rabbit affinity- } \\
\text { purified polyclonal }\end{array}$ & & $\begin{array}{l}\text { Santa Cruz } \\
\text { Biotechnology }\end{array}$ & sc-612 & 0.25 & Trypzination \\
\hline $\begin{array}{l}\text { Monoclonal mouse } \\
\text { anti-human p53 } \\
\text { protein, clone DO-7 }\end{array}$ & IgG2b kappa & DakoCytomation & M7001 & 4 & HIER \\
\hline $\begin{array}{l}\text { PCNA mouse } \\
\text { monoclonal }\end{array}$ & $\operatorname{IgG} 2 \mathrm{a}$ & $\begin{array}{l}\text { Santa Cruz } \\
\text { Biotechnology }\end{array}$ & sc-56 & 1 & NP40 \\
\hline $\begin{array}{l}\text { TGFß3 rabbit affinity- } \\
\text { purified polyclonal }\end{array}$ & & $\begin{array}{l}\text { Santa Cruz } \\
\text { Biotechnology }\end{array}$ & sc- 82 & 0.25 & Trypzination \\
\hline TUNEL AP Kit & & Roche Diagnostics & 1772457 & NA & NA \\
\hline $\begin{array}{l}\text { Rabbit anti-human von } \\
\text { Willebrant factor }\end{array}$ & & DakoCytomation & A 082 & 21.6 & Trypzination \\
\hline
\end{tabular}

Two independent investigators (C. Cahlin and C. Lönnroth) assessed the intensity and extent of the IHC staining. In $\sim 90 \%$ there was an immediate agreement between the investigators. In the remaining cases reevaluations were performed until consensus was reached. The assessments were performed with a microscope (Nikon Eclipse E400) at magnification $\mathrm{x} 40$. All sections were also recorded with a microscope video camera (Sony Digital Hyper HAD Color Video Camera) with pictures analyzed in Easy Image analysis software (Tekno Optik AB, Sweden). This study was approved by the committee for ethics at the Medical Faculty at Göteborg University.

Statistical analyses. Protein staining in tumor cells and stroma was evaluated by non-parametric statistics, while some other biochemical analyses were evaluated and presented by parametric statistics. Survival curves were calculated according to Kaplan-Meier and tested by the log-rank technique.
Patients with death unrelated to colorectal cancer were not censored since their survival may have been influenced in part by different biology among the tumors. Multivariate analyses were performed by various models of regression analyses since estimates of protein staining of specific growth-factors in our applied experiments was close to linear proportionality regarding both staining and quantification as confirmed in pilot evaluations with the microscope video camera system and subsequent analysis in the Easy Image soft technique. Staining of specific tissue proteins among individual tumors had comparable variance.

\section{Results}

Patient and tumor characteristics. This study comprised 7 males and 15 females with a mean age of 75 years with clinical outcome as expected accounting for tumor tissue grade and stage (Fig. 1). The mean follow-up time after operation was 

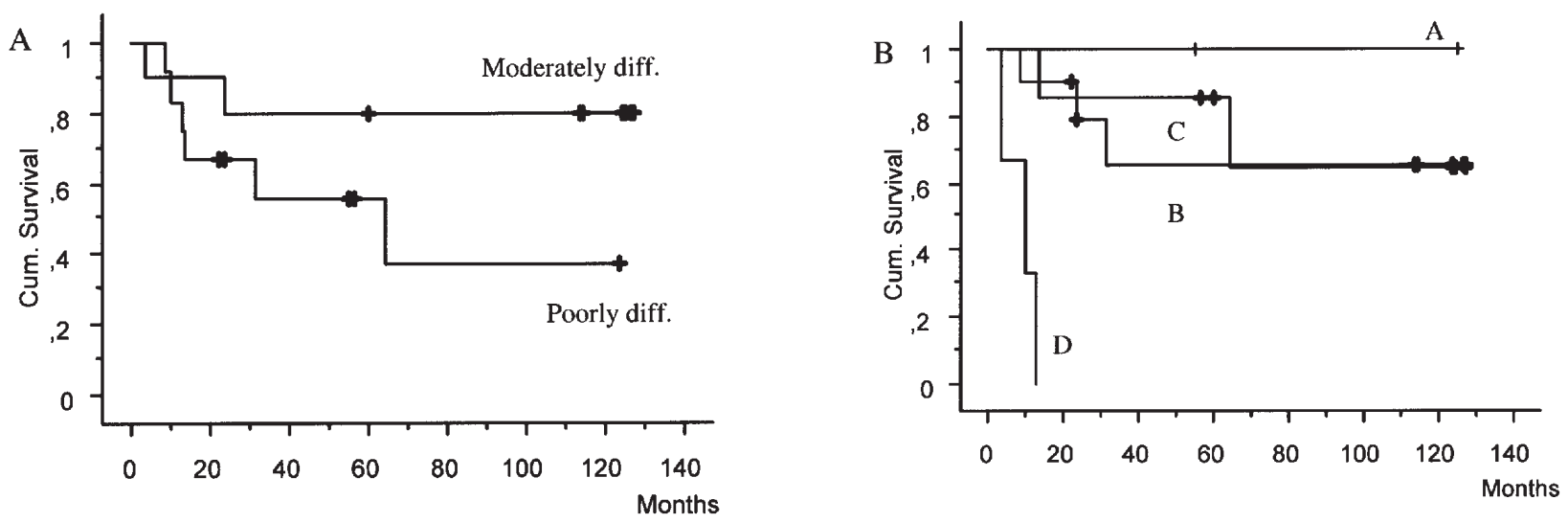

Figure 1. Disease specific survival in relationship to tumor tissue differentiation and Dukes A-D tumor stage.

Table II. Patient and tumor characteristics before operation.

\begin{tabular}{|c|c|c|c|c|}
\hline & $\mathrm{n}$ & & Minimum & Maximum \\
\hline Sex, male/female & $7 / 15$ & & & \\
\hline Age,(years) & $75 \pm 9$ & & 57 & 90 \\
\hline Right side tumors & 21 & & & \\
\hline Left side tumors & 1 & & & \\
\hline \multicolumn{5}{|l|}{ Tumor stage, Dukes (\%) } \\
\hline A & $2(9)$ & & & \\
\hline $\mathrm{B}$ & $10(45)$ & & & \\
\hline $\mathrm{C}$ & $7(32)$ & & & \\
\hline $\mathrm{D}$ & $3(14)$ & & & \\
\hline \multicolumn{5}{|l|}{ Tumor differentiation (\%) } \\
\hline Well & $0 \quad(0)$ & & & \\
\hline Moderate & $10(45)$ & & & \\
\hline Poor & $12(55)$ & & & \\
\hline CRP (mg/l) & 12 & $30 \pm 35$ & 4 & 120 \\
\hline $\operatorname{ESR}(\mathrm{mm} / \mathrm{h})$ & 20 & $28 \pm 26$ & 4 & 110 \\
\hline Tumor $\mathrm{PGE}_{2}(\mathrm{pg} / \mathrm{g})$ & 21 & $18700 \pm 37500$ & 1200 & 180000 \\
\hline Mucosa $\mathrm{PGE}_{2}(\mathrm{pg} / \mathrm{g})$ & 16 & $1700 \pm 1600$ & 100 & 6000 \\
\hline Tumor blood $\mathrm{PGE}_{2}(\mathrm{pg} / \mathrm{ml})$ & 21 & $171 \pm 149$ & 13 & 620 \\
\hline None tumor blood $\mathrm{PGE}_{2}(\mathrm{pg} / \mathrm{ml})$ & 10 & $148 \pm 112$ & 12 & 350 \\
\hline Periph. venous blood $\mathrm{PGE}_{2}(\mathrm{pg} / \mathrm{ml})$ & 20 & $26 \pm 32$ & 10 & 155 \\
\hline Urine $\mathrm{PGE}_{2}$ (ng/mmol creatinine) & 12 & $18 \pm 15$ & 3 & 58 \\
\hline Follow-up (months) & & $68 \pm 50$ & 3.6 & 127.4 \\
\hline Dead & & $13 / 22$ & & \\
\hline Deaths not related to colon cancer & & $5 / 22$ & & \\
\hline
\end{tabular}

Mean \pm SD. Non-tumor blood was collected from a mesenteric vein. ESR, erythrocyte sedimentation rate. CRP, C-reactive protein. Percent within parenthesis. 

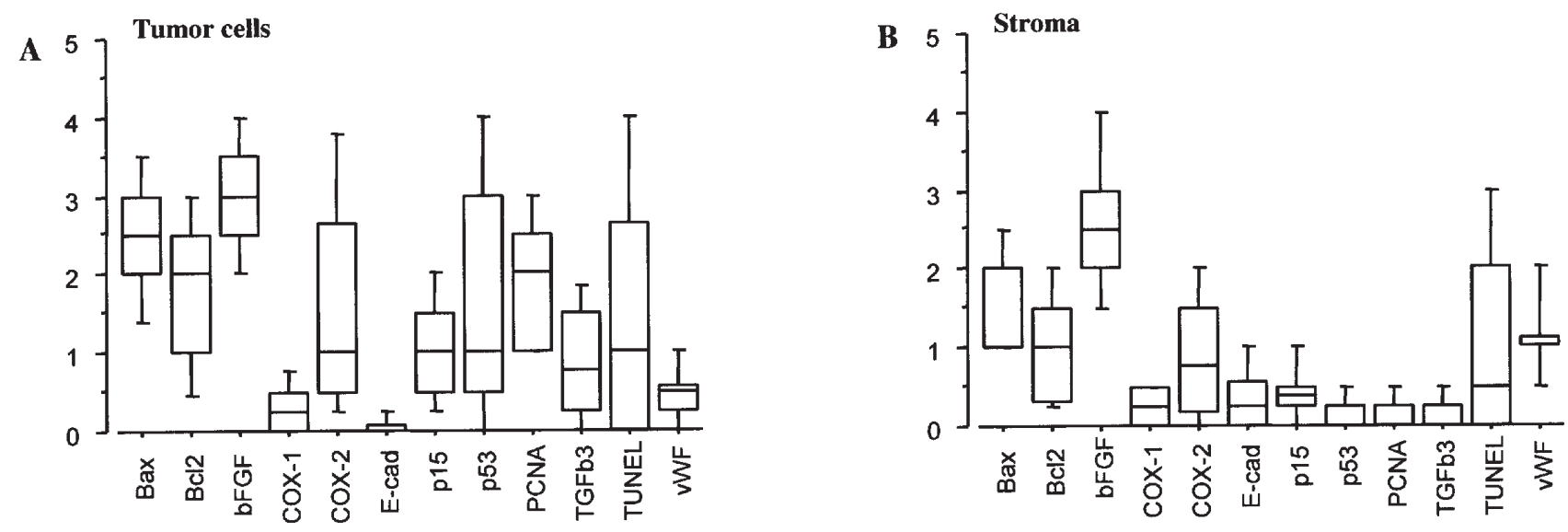

Figure 2. Box-plots, with 10th, 25th, 75th and 90th percentiles indicated for staining of specific proteins in tumor cells and stroma. Zero indicates no staining and 5 indicates maximal staining as described in Patients and methods.

Table III. Protein staining in tumor cells and stroma determined by immunohistochemistry as described in Patients and methods.

\begin{tabular}{|c|c|c|c|c|c|c|}
\hline & Tumor cells & Stroma & $\mathrm{n}$ & p-value ${ }^{a}$ & Correlation coefficient & $\mathrm{p}$-value ${ }^{\mathrm{b}}$ \\
\hline Bax & $2.4 \pm 0.8$ & $1.7 \pm 0.6$ & 63 & $<0.0001$ & 0.64 & $<0.0001$ \\
\hline $\mathrm{Bcl}-2$ & $1.7 \pm 1.1$ & $1.1 \pm 0.7$ & 63 & $<0.0008$ & 0.76 & $<0.0001$ \\
\hline bFGF & $2.9 \pm 0.9$ & $2.6 \pm 0.9$ & 22 & ns & 0.82 & $<0.0001$ \\
\hline $\mathrm{COX}-1$ & $0.3 \pm 0.4$ & $0.2 \pm 0.3$ & 69 & ns & 0.40 & $<0.0005$ \\
\hline $\mathrm{COX}-2$ & $1.7 \pm 1.3$ & $0.9 \pm 0.9$ & 69 & $<0.0001$ & 0.77 & $<0.0001$ \\
\hline E-cad & $0.08 \pm 0.16$ & $0.4 \pm 0.5$ & 25 & $<0.005$ & 0.12 & ns \\
\hline p15 & $1.1 \pm 0.8$ & $0.5 \pm 0.5$ & 68 & $<0.0001$ & 0.72 & $<0.0001$ \\
\hline p53 & $1.7 \pm 1.5$ & $0.14 \pm 0.22$ & 69 & $<0.0001$ & -0.04 & ns \\
\hline PCNA & $1.9 \pm 0.8$ & $0.12 \pm 0.21$ & 60 & $<0.0001$ & 0.27 & $<0.03$ \\
\hline TGFß3 & $0.8 \pm 0.7$ & $0.2 \pm 0.3$ & 68 & $<0.0001$ & 0.44 & $<0.0001$ \\
\hline TUNEL & $1.4 \pm 1.5$ & $1.1 \pm 1.3$ & 69 & $\mathrm{~ns}$ & 0.91 & $<0.0001$ \\
\hline vWF & $0.5 \pm 0.4$ & $1.1 \pm 0.5$ & 25 & $<0.0001$ & -0.55 & $<0.004$ \\
\hline
\end{tabular}

Mean \pm SEM. Fischer's $\mathrm{R}$ to $\mathrm{Z}$ correlations were calculated between protein factors in tumor cells versus corresponding factor in stroma. ${ }^{\mathrm{a}}$ Mann-Whitney test. ${ }^{\mathrm{b}}$ Fisher's $\mathrm{R}$ to $\mathrm{Z}$ test.

68 months where $13 / 22$ patients died as expected. However, $5 / 13$ deaths were not directly related to colon cancer during follow-up. Dukes B and C were most common as expected with a majority of tumors with poor histological differentiation grade. On average patients suffered from comparatively low systemic inflammation. Average $\mathrm{PGE}_{2}$ concentration in tumor tissue was significantly higher compared to adjacent mucosa concentrations $(\mathrm{p}<0.01)$. Blood $\mathrm{PGE}_{2}$ was significantly lower in venous blood from peripheral tissue compared to venous blood originating from the intestinal area $(\mathrm{p}<0.05)$. Tumor derived blood did not contain increased $\mathrm{PGE}_{2}$ concentrations. Urine $\mathrm{PGE}_{2}$ per mol creatinine was within the normal range in all patients (Table II).

Protein staining in tumor cells and tumor stroma. Estimates of protein staining among proteins in tumor cells and tumor stroma are presented in Fig. 2. Bax, Bcl-2, COX-2, p15, p53, PCNA and TGFB3 stained significantly stronger in tumor cells compared to tumor stroma, while bFGF, COX-1 and TUNEL did not differ between the two. By contrast, the von Willebrandt factor (vWF) and membraneous E-cad stained significantly less in tumor cells compared to tumor stroma (Table III). In general there were statistically significant univariate positive correlations between specific staining in tumor cells and tumor stroma for all factors except for p53, vWF and E-cad (Table III). Significant univariate correlations between protein growth-factors within tumor cells and within stroma compartment were observed as shown in Table IV.

Protein staining in tumor cells and stroma related to tumor stage. Protein factors in relation to tumor progression were evaluated by grouping tumors into Dukes $A+B$ and Dukes 
Table IV. Significant correlations between expressions of different proteins within tumor cell and stroma.

\begin{tabular}{|c|c|c|c|c|c|c|c|c|c|c|c|c|}
\hline & Bax & $\mathrm{Bcl}-2$ & bFGF & COX-1 & COX-2 & E-cad & $\mathrm{p} 15$ & p53 & PCNA & TGFß3 & TUNEL & vWF \\
\hline \multirow[t]{2}{*}{ Bax } & $\mathrm{T} 1$ & & & & & & & & & & & \\
\hline & S 1 & & & & & & & & & & & \\
\hline \multirow[t]{2}{*}{ Bcl-2 } & Т 0.67 & 1 & & & & & & & & & & \\
\hline & S 0.54 & 1 & & & & & & & & & & \\
\hline \multirow[t]{2}{*}{ BFGF } & $\mathrm{T}-$ & 0.53 & 1 & & & & & & & & & \\
\hline & S 0.44 & 0.54 & 1 & & & & & & & & & \\
\hline \multirow[t]{2}{*}{ COX-1 } & $\mathrm{T}-$ & - & - & 1 & & & & & & & & \\
\hline & $S-$ & - & - & 1 & & & & & & & & \\
\hline \multirow[t]{2}{*}{$\mathrm{COX}-2$} & Т 0.38 & 0.65 & - & - & 1 & & & & & & & \\
\hline & S 0.30 & 0.55 & - & - & 1 & & & & & & & \\
\hline \multirow[t]{2}{*}{ E-cad } & $\mathrm{T}-$ & - & - & - & 0.48 & 1 & & & & & & \\
\hline & S - & 0.42 & - & 0.55 & - & 1 & & & & & & \\
\hline \multirow[t]{2}{*}{$\mathrm{p} 15$} & Т 0.38 & 0.35 & - & - & 0.47 & - & 1 & & & & & \\
\hline & S - & - & - & - & - & - & 1 & & & & & \\
\hline \multirow[t]{2}{*}{ p53 } & $\mathrm{T}-$ & - & - & 0.31 & 0.27 & - & 0.30 & 1 & & & & \\
\hline & $S-$ & 0.31 & - & - & - & - & - & 1 & & & & \\
\hline \multirow[t]{2}{*}{ PCNA } & $\mathrm{T}-$ & - & - & - & - & - & & - & 1 & & & \\
\hline & S -0.42 & -0.42 & - & - & - & - & -0.26 & - & 1 & & & \\
\hline \multirow[t]{2}{*}{ TGFß3 } & Т 0.28 & 0.59 & - & - & 0.55 & - & 0.37 & - & - & 1 & & \\
\hline & S - & 0.57 & - & - & 0.28 & - & - & 0.35 & - & 1 & & \\
\hline \multirow[t]{2}{*}{ TUNEL } & Т 0.26 & - & - & - & 0.24 & - & 0.49 & - & - & - & 1 & \\
\hline & S 0.34 & - & - & - & - & 0.50 & 0.28 & - & -0.27 & - & 1 & \\
\hline \multirow[t]{2}{*}{ VWF } & $\mathrm{T}-$ & - & - & 0.43 & - & 0.56 & - & 0.69 & - & - & - & 1 \\
\hline & S 0.41 & 0.47 & - & 0.49 & - & 0.75 & - & - & -0.55 & - & - & 1 \\
\hline
\end{tabular}

$\mathrm{T}$, tumor cells. $\mathrm{S}$, stroma cells. $\mathrm{P}<0.05$ for indicated spearman rank correlation coefficients.

$\mathrm{C}+\mathrm{D}$ stages (Mann-Whitney $\mathrm{U}$ test) or by a several group test (Kruskal Wallis) or by regression analysis of protein staining in relation to Dukes A-D tumors (Table V). In these three alternative calculations, COX-1, E-cad and PCNA showed consistently increasing staining from Dukes A to D in stroma, while Bax and bFGF showed significantly decreasing staining in tumor cells and stroma. Other factors did not display systematic trends in tumor tissue content of the proteins along tumor stage or progression (Table V).

Inflammation and survival related to protein staining in tumor cells. C-reactive protein and erythrocyte sedimentation rate are well-recognized markers for systemic inflammation, which predict reduced survival in patients with gastrointestinal cancer $(12,13)$. Multivariate regression analyses (Weibul model; stepwise forward regression analysis) revealed that tumor cell content of p15, TGFß3 and Bcl-2 were significantly related to promotion of systemic inflammation. Increased COX-2 staining predicted tumor tissue content of $\mathrm{PGE}_{2}$ as expected $(\mathrm{p}<0.0002)$, while COX-1 staining was inversely related to tumor tissue $\mathrm{PGE}_{2}$ (Table VI). Stepwise forward regression analyses of survival time vs 12 independent protein growth-factors in tumor and stroma cells respectively showed that Bcl-2, p53 and vWF in tumor cells explained variation in survival (Table VIIA), while in stroma only vWF factor predicted patient survival (Table VIIB).

Growth-factor staining in areas with low or high COX-2 staining. Moderately differentiated tumors displayed significantly higher content of $\mathrm{PGE}_{2}$ compared to poorly differentiated tumors $(\mathrm{p}<0.0001)$, although $\mathrm{PGE}_{2}(\mathrm{pg} / \mathrm{g})$ content in tumor tissue was a significant predictor of reduced survival in multivariate analyses $(\mathrm{p}<0.04) . \mathrm{p} 15$ and $\mathrm{vWF}$ were two other factors in tumor tissue with significant prediction of reduced survival following operation. However, when the tumor group was split according to low and high tissue content of $\mathrm{PGE}_{2}$ different models appeared in prediction of reduced survival (Table VIII).

\section{Discussion}

It has become increasingly clear that arachidonic acid metabolites are important regulators in the control of malignant growth including cell cycling, apoptosis, angio- 
Table V. Specific protein staining in tumor tissue with either increasing or decreasing levels and with levels without any systematic change of protein staining among tumor stage from Dukes A plus B vs C plus D and among Dukes A, B, C and D respectively based on either non-parametric group analysis or regression analysis in tumor cells and stroma.

\begin{tabular}{|c|c|c|c|c|c|}
\hline & & Mann-Whitney & Kruskal-Wallis & $\operatorname{Reg}_{1}$ & analysis \\
\hline & & $\begin{array}{c}\text { Dukes }(\mathrm{A}+\mathrm{B}) \text { vs }(\mathrm{C}+\mathrm{D}) \\
\text { p-value }\end{array}$ & $\begin{array}{l}\text { Dukes A, B, C, D } \\
\text { p-value }\end{array}$ & $\mathrm{r}$ & p-value \\
\hline Increasing & & & & & \\
\hline COX-1 & Tumor & & & 0.14 & $<0.04$ \\
\hline & Stroma & $<0.03$ & $<0.07$ & 0.14 & $<0.003$ \\
\hline E-cad & Tumor & & & & \\
\hline & Stroma & $<0.02$ & $<0.01$ & 0.20 & $<0.03$ \\
\hline PCNA & Tumor & & & & \\
\hline & Stroma & $<0.05$ & $<0.02$ & 0.11 & $<0.0003$ \\
\hline Decreasing & & & & & \\
\hline Bax & Tumor & & $<0.03$ & -0.29 & $<0.01$ \\
\hline & Stroma & & $<0.08$ & -0.20 & $<0.03$ \\
\hline bFGF & Tumor & $<0.03$ & $<0.05$ & -0.48 & $<0.02$ \\
\hline & Stroma & $<0.06$ & & -0.43 & $<0.04$ \\
\hline No system & & & & & \\
\hline Bax & Tumor & & & & \\
\hline & Stroma & & & & \\
\hline $\mathrm{Bcl}-2$ & Tumor & & $<0.02$ & & \\
\hline & Stroma & & $<0.02$ & & \\
\hline bFGF & Tumor & & & & \\
\hline & Stroma & & & & \\
\hline COX-1 & Tumor & & & & \\
\hline & Stroma & & & & \\
\hline COX-2 & Tumor & & $<0.02$ & & \\
\hline & Stroma & & & & \\
\hline E-cad & Tumor & & & & \\
\hline & Stroma & & & & \\
\hline $\mathrm{p} 15$ & Tumor & & & & \\
\hline & Stroma & & & & \\
\hline p53 & Tumor & & $<0.003$ & & \\
\hline & Stroma & & $<0.04$ & & \\
\hline PCNA & Tumor & & & & \\
\hline & Stroma & & & & \\
\hline TGFß3 & Tumor & & & & \\
\hline & Stroma & & $<0.02$ & & \\
\hline TUNEL & Tumor & & & & \\
\hline & Stroma & & $<0.03$ & & \\
\hline vWF & Tumor & & & & \\
\hline & Stroma & & $<0.02$ & & \\
\hline
\end{tabular}

r, correlation coefficient. $\mathrm{p}<0.10$ is indicated as a trend.

genesis as well as local and systemic immune function (14). Colorectal cancer in particular is dependent on cyclo- oxygenase metabolites for progression $(15,16)$. Consequently, aspirin and conventional NSAIDs have been reported to 
Table VI. Multivariate regression analysis (Weibul model) of factors in the systemic (CRP, ESR) and local tumor tissue inflammation (content of $\mathrm{PGE}_{2}$ ) as dependent factor with specific protein staining in tumor tissue as the independent factors.

\begin{tabular}{lccc}
\hline & $\begin{array}{c}\text { Proportional } \\
\text { hazard ratio }\end{array}$ & $\begin{array}{c}\text { 95\% confidence } \\
\text { interval }\end{array}$ & p-value \\
\hline CRP $(\mathrm{p}<0.0001)$ & & & \\
p15 & 2.39 & $1.14-5.03$ & $<0.02$ \\
TGF33 & 1.53 & $1.07-2.18$ & $<0.02$ \\
ESR $(\mathrm{p}<0.0001)$ & & & \\
p15 & 1.73 & $1.27-2.36$ & $<0.0005$ \\
Bcl-2 & 1.43 & $1.0-2.06$ & $<0.05$ \\
PGE $(\mathrm{p}<0.0002)$ & & & \\
COX-1 & 0.43 & $0.28-0.67$ & $<0.0002$ \\
COX-2 & 1.23 & $1.02-1.47$ & $<0.03$ \\
\hline
\end{tabular}

CRP, C-reactive protein (mg/l). ESR, erythrocyte sedimentation rate $(\mathrm{mm} / \mathrm{h}) . \mathrm{PGE}_{2}$ in tumor tissue $(\mathrm{pg} / \mathrm{g})$. CRP, ESR were tested against 12 staining protein factors in tumor tissue as provided in Table VII, while $\mathrm{PGE}_{2}$ was tested against COX-1 and COX-2 staining only.

attenuate several steps in disease progression of polyps and subsequent invasive growth of tumor cells (17-20), but a recent analysis suggested that this protection may only relate to a defined group of tumors (9). In this context, COX-2 is regarded the key enzyme for local cellular production of $\mathrm{PGE}_{2}$, without previous direct demonstration of importance for human tumor growth in vivo. Accordingly, our own studies have suggested indirect relationships between $\mathrm{PGE}_{2}$ and tumor growth (2), although, it is a general view that upregulation of COX-2 may represent a global phenomenon in malignancy. By contrast, our own studies have indicated that tumor content of COX-2 transcript and protein are not necessarily overall increased in colorectal tissue, although locally high concentrations are recognized as 'hot spots' (8). This is not a unique finding for COX-2, since most growthfactors stain with uneven distribution among tumor cells in malignant tissue, which is a composite compartment consisting of different clones of tumor cells, stroma, endothelial and inflammatory cells. Therefore, it is difficult to make general conclusions about tumors and expected patient outcome based on the histological appearance of growth-factor characteristics and corresponding interactions between regulators within tumor and stroma cells, as well as among tumor cells and other host cells. Thus, it is possible that clinical progression of solid tumors may well depend on growth-factor interactions in minor areas of a tumor rather than on the basis of the overall tumor content of growthrelated proteins

It is important to understand the relationships between key-factors in the control of net tumor growth based on our interest in the role of eicosanoids in control and progression of colorectal cancer $(8,21)$. So far, most attention has been
Table VIIA. Stepwise forward regression analysis of survival vs 12 independent proteins in tumor cells.

\begin{tabular}{lrcr}
\hline Antigen & $\begin{array}{c}\text { Regression } \\
\text { coefficient }\end{array}$ & $\begin{array}{c}\text { Standardized } \\
\text { coefficient }\end{array}$ & p-value \\
\hline Bcl-2 & $\mathbf{5 3 0}$ & $\mathbf{0 . 3 4}$ & $<\mathbf{0 . 0 1}$ \\
$\mathbf{p 5 3}$ & $\mathbf{- 1 5 4}$ & $\mathbf{- 0 . 4 1}$ & $\mathbf{< 0 . 0 1}$ \\
$\mathbf{v W F}$ & $\mathbf{- 1 9 5 1}$ & $\mathbf{0 . 5 8}$ & $\mathbf{< 0 . 0 1}$ \\
Bax & & & \\
bFGF & & & \\
COX-1 & & & \\
COX-2 & & & \\
E-cad & & & \\
PCNA & & & \\
p15 & & & \\
TGF $\beta 3$ & & & \\
TUNEL & & & \\
\hline
\end{tabular}

Regression significance $\mathrm{p}<0.0002 . \mathrm{r}^{2}=0.88$

B, Stepwise forward regression analysis of survival vs 12 independent proteins in tumor stroma.

\begin{tabular}{lccr}
\hline Antigen & $\begin{array}{c}\text { Regression } \\
\text { coefficient }\end{array}$ & $\begin{array}{c}\text { Standardized } \\
\text { coefficient }\end{array}$ & p-value \\
\hline $\mathbf{v W F}$ & $\mathbf{7 1 2}$ & $\mathbf{0 . 7 0}$ & $\mathbf{< 0 . 0 1}$ \\
Bax & & \\
Bcl-2 & & \\
bFGF & & \\
COX-1 & & \\
COX-2 & & \\
E-cad & & \\
PCNA & & \\
p 53 & & \\
p15 & & \\
TGF $\beta 3$ & & \\
TUNEL & & \\
\hline
\end{tabular}

Regression significance $\mathrm{p}<0.008 \cdot \mathrm{r}^{2}=0.49$.

paid to gene expression in colorectal cancer in part dependent on the remarkable development in biochemistry, PCR and microarray technology. Accordingly, we have observed that subtype EP receptor expressions are important to explain progression of colorectal cancer, while COX-2 expression was not universally increased in tumor tissue (8). Also, comparatively little information is available on the relationship between growth-factors at the protein level for colon cancer progression (8). It has never been directly demonstrated and reported that tissue prostaglandins are predictors of disease progression, although it is known that some tumors contain 
Table VIII. Multivariate regression analysis (Weibul model) of factors predicting elevated risk for reduced survival following radical resection of colon cancer.

\begin{tabular}{lccc}
\hline & $\begin{array}{c}\text { Proportional } \\
\text { hazard ratio }\end{array}$ & $\begin{array}{c}\text { 95\% confidence } \\
\text { interval }\end{array}$ & p-value \\
\hline $\begin{array}{l}\text { Ungrouped } \\
(\mathrm{p}<0.02)\end{array}$ & & & \\
p15 & 2.34 & $1.34-4.07$ & $<0.002$ \\
vWF & 2.58 & $0.99-6.74$ & $<0.05$ \\
PGE 2 & 1.00 & $1.00-1.15$ & $<0.04$ \\
& & & \\
Low PGE & & & \\
$(\mathrm{p}<0.0004)$ & & $1.66-3.57$ & $<0.001$ \\
Bax & 2.44 & $1.20-2.01$ & $<0.007$ \\
PCNA & 1.57 & & \\
High PGE & & & \\
$(\mathrm{p}<0.0001)$ & & & $<0.0001$ \\
p15 & & $2.37-3.44$ & $<0.0001$ \\
PCNA & 2.86 & $1.08-1.24$ & $<0.0003$ \\
TGFB3 & 1.15 & $1.26-2.97$ & \\
vWF & 6.93 & $4.08-9.90$ & $<01$ \\
\hline
\end{tabular}

Ungrouped are all patients, split into tumors with low (below median) and high (above median) content of $\mathrm{PGE}_{2}$. Dependent factor was disease-specific survival with alive patients being censored. Independent factors were: Bax, Bcl-2, bFGF, E-cad, p15, p53, PCNA, TGFß3, TUNEL, vWF and $\mathrm{PGE}_{2}(\mathrm{pg} / \mathrm{g})$ in tumor tissue.

high levels of $\mathrm{PGE}_{2}$. Limited knowledge on this point is in part due to technical difficulties in measuring eicosanoids due to molecular instability. Also, quantification of protein components in tissue sections only represent estimates of true cellular levels with a considerable methodological variation. Despite such uncertainties we found it important to try to link different protein key-factors to disease progression of colorectal cancer in an attempt of mathematical modeling. With this purpose, disease progression was defined by tumor stage and host systemic inflammation, which is a significant predictor of reduced survival in patients with gastrointestinal malignances $(22,23)$.

The various protein key-factors were chosen for the present analyses based on general aspects of tumor cell growth as a consequence of proliferation, apoptosis, local tissue inflammation, tumor cell adhesion and tumor tissue vascularity. Dukes' staging of colorectal cancer represents a universal prediction of outcome independently of race, sex and age with comparable results across countries (24). Based on these prerequisites we collected tumor material from unselected patients at primary operation for curative resection of newly diagnosed colorectal cancer. Immunohistochemical staining was related to tissue and blood concentration of $\mathrm{PGE}_{2}$ as a hall mark of COX activity. Staining of key-proteins was then evaluated in relationship to tumor stage and survival in both uni- and multivariate analyses. The results demonstrate significant relationships among several key-proteins within tumor cells and stroma as well as among factors in tumor cells and stroma. Significant and positive correlations as well as increased hazard ratios may thus represent overall elevated functional cell activities, while negative correlations or decreased hazard ratios suggest opposite function. Multivariate analysis among dependent and independent factors suggests relationships within a specified context of factors, while step-wise forward analysis should represent an approach to select factors that may explain variations in prediction more independently. Such significant results must always be interpreted with caution since they may not represent general phenomena under all conditions and circumstances. Statistically significant results should however indicate explorative models and represent a valid base for future research. Based on this opinion, we demonstrated significant relationships between host systemic inflammation, survival and protein staining of growth related proteins in tumor cells and stroma (Tables VI and VII). Other interesting and unexpected indications were that Bcl-2 expression in tumor cells and vWF in stroma were associated with prolonged survival while staining of p53 and vWF in tumor cells where related to reduced survival (Table VII). Bcl-2 is regarded an inhibitor of apoptosis (25), although it has recently been reported that $\mathrm{Bcl}-2$ protein was related to improved prognosis of colorectal cancer (26). Opposing, dual function of Bcl-2 was explained by interaction with the orphan nuclear receptor Nur77 bound to Bcl-2 and induced conformational changes that may convert Bcl-2 from an inhibitor to a promoter of apoptosis (25).

This is also the first report that demonstrates a statistically significant relationship between tumor tissue COX-1/COX-2 staining and overall tumor tissue content of $\mathrm{PGE}_{2}$ in human colon cancer in vivo. High COX-2 content suggests elevated tumor $\mathrm{PGE}_{2}$, while high COX-1 content rather predicted the opposite. This divergence may be a question of less maintained physiology in tumor tissue with little retained intestinal morphology and function from its original normal mucosa, which is the main reservoir for COX-1 protein. Also, our results are the first indication of a direct relationship between tumor cell proliferation and elevated host systemic inflammation in colon cancer patients, evaluated by $\mathrm{p} 15$, TGFB3 and Bcl-2 staining, although such relationships may be indirect. However, it is well recognized that local and systemic inflammation relate to poor prognosis in colorectal cancer (22,23). Accordingly, relationships between COX-2 expression, $\mathrm{PGE}_{2}$ content and survival indicated different relationship in tumors with low and high $\mathrm{PGE}_{2}$ suggesting that vWF was a risk factor for reduced survival. This conclusion agrees with other observations in colorectal cancer, such that increased angiogenesis is a sign of poor prognosis. Previous and present results link $\mathrm{PGE}_{2}$ as a mediator in this pathway $(8,27)$, although it may be that von Willebrant factor activates simultaneously different pathways in tumor epithelial and endothelial cells within the tumor. Thus, von Willebrant protein could have different net effects in determination of tumor cell proliferation and development of tumor vascularity, which may secondarily affect the possibility for immune cells to execute anti-tumor effects in different parts of a 
tumor (28). Based on these speculations, it is obvious that microdissection of defined compartment and further isolation of different cells in colon cancer is necessary for definite evaluation of specific interactions and control phenomena in composite tissues such as solid malignant tumors.

In conclusion, the present study emphasized well-recognized tissue and functional heterogeneity of colon cancer. Certain protein factors predicted systemic inflammation, which in itself is a predictor of reduced survival $(22,23)$. Our results also demonstrate significant relationship between COX-1/COX-2 staining and overall $\mathrm{PGE}_{2}$ concentrations in colon cancer tissue obtained at operation. Various growth related protein factors explained variation in patient survival when tumors were grouped according to low and high overall content of $\mathrm{PGE}_{2}$, which is in line with recent observations from epidemiological research (9). Therefore, it seems important to understand the proximal signals for local upregulation of COX-2 and subsequent $\mathrm{PGE}_{2}$ production in different parts of colorectal cancer.

\section{Acknowledgements}

This stydy was supported in parts by grants from the Swedish Cancer Society (2014), the Swedish Research Council (08712), Tore Nilson Foundation, Assar Gabrielsson Foundation (AB Volvo), Jubileumskliniken foundation, Inga-Britt \& Arne Lundberg Research Foundation, Swedish and Göteborg Medical Societies and the Medical Faculty, Göteborg University, VGR 19/00, 1019/00.

\section{References}

1. Patocs A, Zhang L, Xu Y, Weber F, Caldes T, Mutter GL, Platzer P and Eng C: Breast-cancer stromal cells with TP53 mutations and nodal metastases. N Engl J Med 357: 2543-2551, 2007.

2. Cahlin C, Gelin J, Andersson M, Lönnroth C and Lundholm K: The effects of non-selective, preferential-selective and selective COX-inhibitors on the growth of experimental and human tumors in mice related to prostanoid receptors. Int J Oncol 27: 913-923, 2005.

3. Hwang JT, Kim YM, Surh YJ, Baik HW, Lee SK, Ha J and Park OJ: Selenium regulates cyclooxygenase-2 and extracellular signal-regulated kinase signaling pathways by activating AMPactivated protein kinase in colon cancer cells. Cancer Res 66: 10057-10063, 2006.

4. Pai R, Soreghan B, Szabo IL, Pavelka M, Baatar D and Tarnawski AS: Prostaglandin E2 transactivates EGF receptor: a novel mechanism for promoting colon cancer growth and gastrointestinal hypertrophy. Nat Med 8: 289-293, 2002.

5. Elder DJ and Paraskeva C: COX-2 inhibitors for colorectal cancer [news]. Nat Med 4: 392-393, 1998.

6. De Leval X, Delarge J, Somers F, de Tullio P, Henrotin Y, Pirotte B and Dogne JM: Recent advances in inducible cyclooxygenase (COX-2) inhibition. Curr Med Chem 7: 1041-1062, 2000 .

7. Castellone MD, Teramoto H, Williams BO, Druey KM and Gutkind JS: Prostaglandin E2 promotes colon cancer cell growth through a Gs-axin-beta-catenin signaling axis. Science 310: 1504-1510, 2005

8. Gustafsson A, Hansson E, Kressner U, Nordgren S, Andersson M, Wang W, Lonnroth C and Lundholm K: EP(1-4) subtype, COX and PPARgamma receptor expression in colorectal cancer in prediction of disease-specific mortality. Int J Cancer 121: 232-240, 2007.

9. Chan AT, Ogino S and Fuchs CS: Aspirin and the risk of colorectal cancer in relation to the expression of COX-2. N Engl $\mathrm{J}$ Med 356: 2131-2142, 2007.
10. Astler VB and Coller FA: The prognostic significance of direct extension of carcinoma of the colon and rectum. Ann Surg 139: 846-852, 1954.

11. Waseem NH and Lane DP: Monoclonal antibody analysis of the proliferating cell nuclear antigen (PCNA). Structural conservation and the detection of a nucleolar form. J Cell Sci 96: 121-129, 1990.

12. Lundholm K, Daneryd P, Korner U, Hyltander A and Bosaeus I: Evidence that long-term COX-treatment improves energy homeostasis and body composition in cancer patients with progressive cachexia. Int J Oncol 24: 505-512, 2004.

13. Fouladiun M, Körner U, Bosaeus I, Daneryd P, Hyltander A and Lundholm K: Body composition and time course changes in regional distribution of fat and lean tissues in unselected cancer patients on palliative care. Correlations with food intake, metabolism, exercise capacity and hormones. Cancer 103: 2189-2198, 2005.

14. Ruegg C, Dormond O and Mariotti A: Endothelial cell integrins and COX-2: mediators and therapeutic targets of tumor angiogenesis. Biochim Biophys Acta 1654: 51-67, 2004.

15. Ferrandez A, Prescott S and Burt RW: COX-2 and colorectal cancer. Curr Pharm Des 9: 2229-2251, 2003.

16. Shin VY, Wu WK, Ye YN, So WH, Koo MW, Liu ES, Luo JC and Cho $\mathrm{CH}$ : Nicotine promotes gastric tumor growth and neovascularization by activating extracellular signal-regulated kinase and cyclooxygenase-2. Carcinogenesis 25: 2487-2495, 2004.

17. Sandler RS, Halabi S, Baron JA, Budinger S, Paskett E, Keresztes R, Petrelli N, Pipas JM, Karp DD, Loprinzi CL, Steinbach G and Schilsky R: A randomized trial of aspirin to prevent colorectal adenomas in patients with previous colorectal cancer. N Engl J Med 348: 883-890, 2003.

18. Baron JA, Cole BF, Sandler RS, Haile RW, Ahnen D, Bresalier R, McKeown-Eyssen G, Summers RW, Rothstein R, Burke CA, Snover DC, Church TR, Allen JI, Beach M, Beck GJ, Bond JH, Byers T, Greenberg ER, Mandel JS, Marcon N, Mott LA, Pearson L, Saibil F and van Stolk RU: A randomized trial of aspirin to prevent colorectal adenomas. N Engl J Med 348: 891-899, 2003.

19. Asano TK and McLeod RS: Non-steroidal anti-inflammatory drugs and aspirin for the prevention of colorectal adenomas and cancer: a systematic review. Dis Colon Rectum 47: 665-673, 2004.

20. Chan AT, Giovannucci EL, Schernhammer ES, Colditz GA, Hunter DJ, Willett WC and Fuchs CS: A prospective study of aspirin use and the risk for colorectal adenoma. Ann Intern Med 140: 157-166, 2004.

21. Gustafsson A, Hansson E, Kressner U, Nordgren S, Andersson M, Lönnroth C and Lundholm K: Prostanoid receptor expression in colorectal cancer related to tumor stage, differentiation and progression. Acta Oncol (In press).

22. Lundholm K, Gelin J, Hyltander A, Lonnroth C, Sandstrom R, Svaninger G, Korner U, Gulich M, Karrefors I, Norli B, Hafström L, Kewenter J, Olbe L and Lundell L: Anti-inflammatory treatment may prolong survival in undernourished patients with metastatic solid tumors. Cancer Res 54: 5602-5606, 1994.

23. Lönnroth C, Körner U, Larsson B, Henriksson BA and Lundholm K: Survival and erythropoietin receptor protein in tumors from patients randomly treated with rhEPO in palliative care. Med Oncol (In press)

24. Bosman FT: Prognostic value of pathological characteristics of colorectal cancer. Eur J Cancer 31A: 1216-1221, 1995.

25. Lin B, Kolluri SK, Lin F, Liu W, Han YH, Cao X, Dawson MI, Reed JC and Zhang XK: Conversion of Bcl-2 from protector to killer by interaction with nuclear orphan receptor Nur77/TR3. Cell 116: 527-540, 2004.

26. Leahy DT, Mulcahy HE, O'Donoghue DP and Parfrey NA: $\mathrm{Bcl}-2$ protein expression is associated with better prognosis in colorectal cancer. Histopathology 35: 360-367, 1999.

27. Axelsson H, Lönnroth C, Wang W, Svanberg E and Lundholm K: Cyclooxygenase inhibition in early onset of tumor growth and related angiogenesis evaluated in EP1 and EP3 knockout tumorbearing mice. Angiogenesis 8: 339-348, 2005.

28. Ogino T, Shigyo H, Ishii H, Katayama A, Miyokawa N, Harabuchi Y and Ferrone S: HLA class I antigen downregulation in primary laryngeal squamous cell carcinoma lesions as a poor prognostic marker. Cancer Res 66: 9281-9289, 2006 . 